\title{
Biology of the king crab Paralomis birsteini on the continental slope off the western Antarctic Peninsula
}

\author{
Kathryn E. Smith ${ }^{1,2}$ (D) Richard B. Aronson ${ }^{1} \cdot$ Sven Thatje $^{3} \cdot$ Gustavo A. Lovrich $^{4}$ • \\ Margaret O. Amsler $^{5} \cdot$ Brittan V. Steffel $^{1} \cdot$ James B. McClintock $^{5}$
}

Received: 16 January 2017/Revised: 25 May 2017/ Accepted: 12 June 2017 / Published online: 21 June 2017

(C) The Author(s) 2017. This article is an open access publication

\begin{abstract}
Predatory king crabs (Lithodidae) structure benthic communities in their native habitats and cause shifts in the composition of benthic assemblages when introduced to new environments. Cold temperatures have apparently excluded skeleton-breaking predators from the continental shelf around Antarctica for millions of years, but recent increases in sea temperatures off the western Antarctic Peninsula (WAP) may be allowing lithodids to return. Imaging surveys have revealed dense populations of the lithodid Paralomis birsteini (Macpherson 1988) living on the continental slope off the WAP, but the biology of these populations remains poorly understood. We collected 51 adult $P$. birsteini in a trapping study on the slope off Marguerite Bay, WAP from depths of 1200-1400 m. Of the 51 crabs, 42 were males and 9 were females. Four females were ovigerous, carrying eggs at various stages of development. Rates of parasitism and limb regeneration were comparable to populations of lithodids elsewhere in the world, although the proportion of limb loss was
\end{abstract}

Kathryn E. Smith

k.e.smith@exeter.ac.uk

1 Department of Biological Sciences, Florida Institute of Technology, 150 West University Boulevard, Melbourne, FL 32901, USA

2 Present Address: College of Life and Environmental Sciences, University of Exeter, Exeter EX4 4QD, UK

3 Ocean and Earth Science, National Oceanography Centre Southampton, University of Southampton, European Way, Southampton SO14 3ZH, UK

4 Centro Austral de Investigaciones Científicas y Técnicas (CADIC-CONICET), Houssay 200, V9410CAB Ushuaia, Tierra del Fuego, Argentina

5 Department of Biology, University of Alabama at Birmingham, Birmingham, AL 35294, USA relatively high. Externa of the parasite Briarosaccus callosus was obvious in both males and females, with one individual bearing hyperparasites (probably Liriopsis pygmaea). Gill necrosis was also observed in several dissected males. The success of contemporary lithodid populations on the Antarctic slope suggests they have the potential to expand upward to the continental shelf.

Keywords Lithodidae P Paralomis - Southern Ocean · Briarosaccus · Ovigerous · Parasitism

\section{Introduction}

King crabs (Crustacea: Decapoda: Anomura: Lithodidae) are found in the deep sea globally and in shallow water at subpolar latitudes (Hall and Thatje 2009). They predominantly inhabit cold-water environments, but a physiological intolerance of temperatures below $\sim 0.4{ }^{\circ} \mathrm{C}$ has apparently excluded them and other skeleton-crushing (durophagous) decapods from the Antarctic shelf for millions of years (Thatje et al. 2005; Aronson et al. 2007; Hall and Thatje 2011). Durophagous predators structure benthic communities in nearshore, subtidal environments outside of Antarctica, and introductions of decapods to seafloor environments have caused major shifts in the benthic assemblages. Deliberate introduction of the red king crab Paralithodes camtschaticus in the Barents Sea has led to a marked reduction in epifaunal and infaunal invertebrates at some coastal locations (Britayev et al. 2010; Falk-Petersen et al. 2011; Oug et al. 2011). Likewise, the introduced green crab Carcinus maenas has significantly reduced the abundances of benthic invertebrates in the areas of North America that it has invaded (Grosholz et al. 2000). 
Seawater temperatures are rising at an unprecedented rate globally (Molinos et al. 2015), with some of the most rapid increases occurring over the continental shelf off the western Antarctic Peninsula (WAP; Schmidtko et al. 2014). Historically, low temperatures and the related absence of durophagous predators on the Antarctic shelf have together fostered benthic assemblages of invertebrate prey that are poorly equipped to resist skeleton-crushing predation (Watson et al. 2012). Warming waters, however, may soon allow predatory lithodids to return to shelf habitats, and the geologically sudden increase in durophagous predation could have important consequences for benthic food webs (Thatje et al. 2005; Aronson et al. 2007). Lithodids were first recorded on the continental slope off the WAP in 1998 (Arana and Retamal 1999). Seafloor-imaging studies have since revealed that populations of the lithodid Paralomis birsteini are widespread on the slope off the WAP, with densities of $\sim 4500$ ind $\cdot \mathrm{km}^{-2}$ reported at depths of 1100-1500 m off Marguerite Bay (Aronson et al. 2015). Individual lithodids have been recorded as shallow as $621 \mathrm{~m}$ off the sub-Antarctic islands and at $721 \mathrm{~m}$ on the Antarctic slope, close to the shelf-break at $\sim 500 \mathrm{~m}$ (Arana and Retamal 1999; Aronson et al. 2015). Adults, juveniles, exuviae, and pairs of individuals in precopulatory embrace were observed in images, strongly suggesting the population is well established and reproductively viable (Aronson et al. 2015). Considering the poor antipredatory defenses exhibited by the native invertebrates (Watson et al. 2012), most of which are endemic, the return of durophagous predators to the Antarctic shelf could restructure the benthic communities (Thatje et al. 2005; Aronson et al. 2007, 2015).

Collections of lithodids from Antarctic waters are scant, and consequently their biology remains poorly understood. Observations have typically consisted of individuals recovered opportunistically by trawls or remotely operated underwater vehicles, or found in the stomachs of the commercially exploited Antarctic toothfish, Dissostichus mawsoni (e.g., Ahyong and Dawson 2006; Thatje et al. 2008; but see Arana and Retamal 1999 for an exploratory fisheries survey). To gain a better understanding of populations of lithodids in Antarctica, we collected individuals in a deep-water trapping study off the WAP. Here, we describe the biology of one such population. This paper provides biological data to complement the results published by Aronson et al. (2015).

\section{Materials and methods}

We conducted the crab-trapping study in 2015 during National Science Foundation cruise LMG15-02 aboard the $R V$ Laurence M. Gould. The study area consisted of a
$100 \times 100-\mathrm{km}$ area off Marguerite Bay (MB), WAP centered at $66^{\circ} 42^{\prime} \mathrm{S}, 72^{\circ} 12^{\prime} \mathrm{W}$ (Fig. 1a). Crab pots were deployed on the slope at depths of approximately 1200-1400 m.

Six crab-pot deployments were carried out over 13 days in February and March 2015. Each deployment consisted of a string of six Chilean crab pots (Fig. 1b, c). The pots were conical in shape, $142 \mathrm{~cm}$ in diameter, and separated by $40 \mathrm{~m}$ of line. The pots were covered in $25 \mathrm{~mm}$ rope mesh and baited with pieces of commercially purchased, frozen sardine, Sardinops sagax. The average soak-time of the deployments was $32 \mathrm{~h}$ (Table 1).

Upon recovery of the pots, the crabs we collected were sexed and weighed, and morphometric measurements were recorded (Fig. 1d; Table 2): carapace length (CL) and carapace width $(\mathrm{CW})$; the lengths, widths, and heights of the chelae; and the merus-lengths of the pereopods. Sexual dimorphism was examined using twotailed $t$-tests to compare the measurements of CL between males and females and, separately, the measurements of CW. Paired, one-tailed $t$-tests were used to compare CL with CW for males and, separately, for females. To test for sexual differences in claw dimorphism, the ratios of heights of the major-to-minor chelae were compared between males and females using a one-tailed Welch's $t$ test. These latter tests were one-tailed because mature male $P$. birsteini typically display greater claw dimorphism than mature females, and in both sexes carapaces are longer than they are wide (Ahyong and Dawson 2006). Morphometric relationships between $\ln (\mathrm{CL})$ and $\ln$ (wet-weight), $\ln (\mathrm{CL})$ and $\ln$ (major chela height), and $\ln (\mathrm{CL})$ and $\ln (\mathrm{CW})$ were plotted for both males and females. Spearman rank correlations were run on each pair of variables. Non-parametric correlation was used to avoid problems associated with violations of the assumptions of parametric statistics. Individuals were examined for parasites, epibionts, carapace and limb damage, and missing or regenerating limbs. Lithodids, like most crustaceans, are bilaterally symmetrical and opposing pereopods 2-4 are of approximately equal length when fully formed. Lost pereopods regenerate slowly, increasing in size with each consecutive moult (Edwards 1972; Lysenko et al. 2000; Selin 2003). The sizes of paired pereopods were plotted against each other (three pairs per crab, male and female data pooled), with an expected slope of 1 for fully formed pairs. All outliers in the dataset were considered to represent regenerating pereopods. Outliers were identified as values falling outside 1.5 times the interquartile range below the lower quartile or above the upper quartile of the dataset. Regenerating chelae were not as easy to identify due to their asymmetry in the undamaged state. Only chelae that were qualitatively smaller than expected were considered 

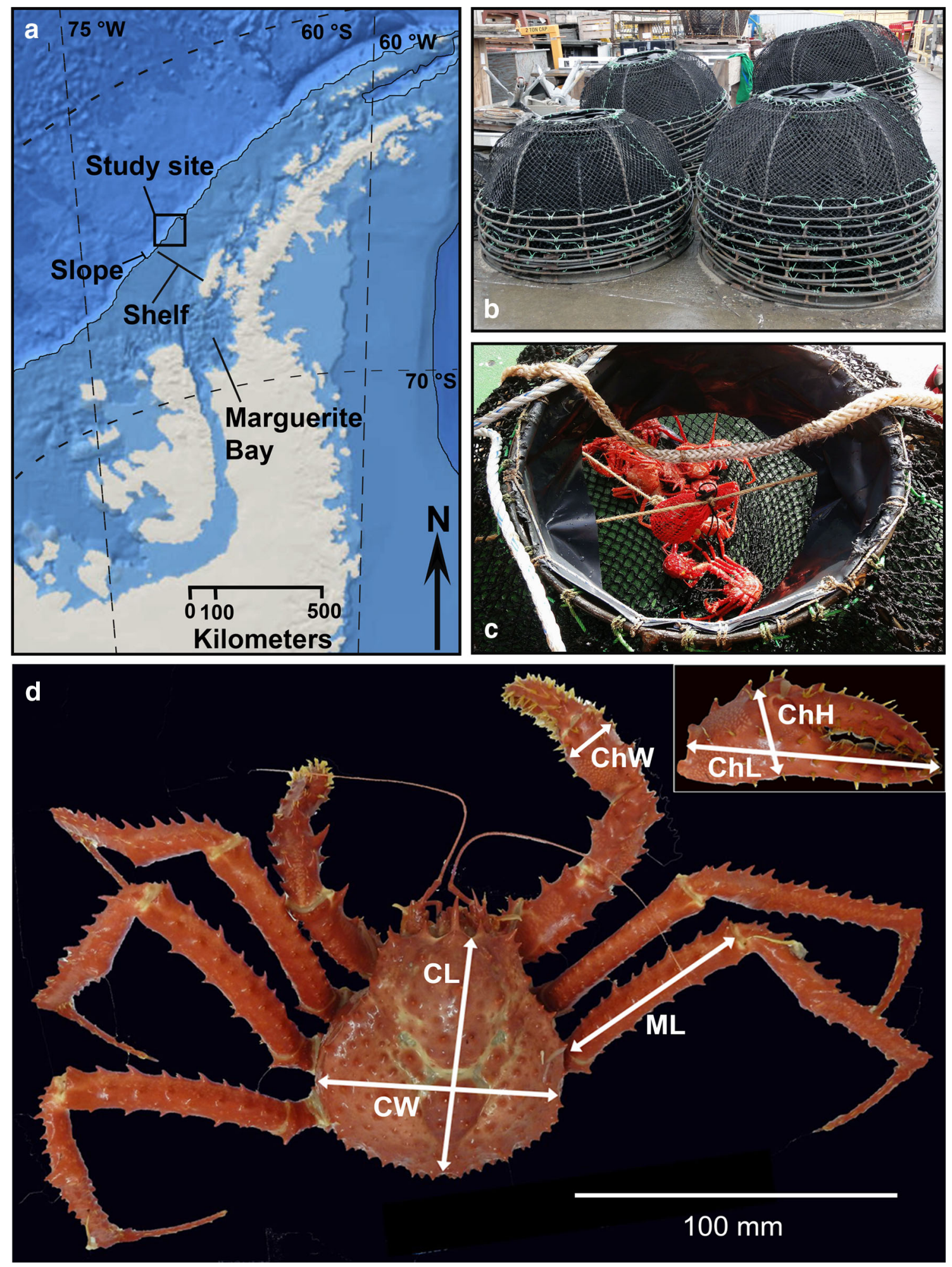

Fig. 1 a Location of study site off Marguerite Bay, western Antarctic Peninsula. The $500 \mathrm{~m}$ depth contour is marked. Constructed in ArcGIS 10.2. b Stacks of Chilean crab pots. c Crab pot containing 11 Paralomis birsteini trapped on the upper continental slope off
Marguerite Bay. d Morphometric measurements of $P$. birsteini collected from the study site. Abbreviations $C L$ carapace length, $C W$ carapace width, $M L$ merus length, $C h W$ chela width, $C h L$ chela length, $\mathrm{ChH}$ chela height 
Table 1 Deployments of crab traps off Marguerite Bay, western Antarctic Peninsula during February and March 2015

\begin{tabular}{|c|c|c|c|c|c|}
\hline \multirow[t]{2}{*}{ Deployment \# } & \multicolumn{2}{|l|}{ Location } & \multirow[t]{2}{*}{ Depth } & \multirow[t]{2}{*}{ Duration of deployment } & \multirow[t]{2}{*}{ Paralomis birsteini recovered } \\
\hline & Latitude & Longitude & & & \\
\hline 1 & $66^{\circ} 31.17^{\prime} \mathrm{S}$ & $71^{\circ} 40.90^{\prime} \mathrm{W}$ & $\sim 1400 \mathrm{~m}$ & $18 \mathrm{~h}$ & $12 \mathrm{M}, 1 \mathrm{~F}$ \\
\hline 2 & $66^{\circ} 30.59^{\prime} \mathrm{S}$ & $71^{\circ} 39.43^{\prime} \mathrm{W}$ & $\sim 1300 \mathrm{~m}$ & $23 \mathrm{~h}$ & $5 \mathrm{M}, 4 \mathrm{~F}$ \\
\hline 3 & $66^{\circ} 33.12^{\prime} \mathrm{S}$ & $71^{\circ} 42.93^{\prime} \mathrm{W}$ & $\sim 1300 \mathrm{~m}$ & $44 \mathrm{~h}$ & $17 \mathrm{M}, 1 \mathrm{~F}$ \\
\hline 4 & $66^{\circ} 49.05^{\prime} \mathrm{S}$ & $72^{\circ} 21.18^{\prime} \mathrm{W}$ & $\sim 1250 \mathrm{~m}$ & $47 \mathrm{~h}$ & $1 \mathrm{M}$ \\
\hline 5 & $66^{\circ} 34.00^{\prime} \mathrm{S}$ & $71^{\circ} 44.36^{\prime} \mathrm{W}$ & $\sim 1400 \mathrm{~m}$ & $22 \mathrm{~h}$ & $6 \mathrm{M}, 1 \mathrm{~F}$ \\
\hline 6 & $66^{\circ} 29.83^{\prime} \mathrm{S}$ & $71^{\circ} 38.30^{\prime} \mathrm{W}$ & $\sim 1200 \mathrm{~m}$ & $40 \mathrm{~h}$ & $1 \mathrm{M}, 2 \mathrm{~F}$ \\
\hline
\end{tabular}

Depths are approximate because they were taken from the location of the head-gear rather than the realized depth at which traps were deployed

Table 2 Morphometric data on 51 Paralomis birsteini trapped at $\sim 1300 \mathrm{~m}$ off Marguerite Bay, western Antarctic Peninsula in February and March 2015

\begin{tabular}{|c|c|c|c|c|c|c|c|c|}
\hline \multirow[t]{3}{*}{ Morphometric } & \multicolumn{4}{|c|}{ Males } & \multicolumn{4}{|c|}{ Females } \\
\hline & \multirow[t]{2}{*}{$n$} & \multirow[t]{2}{*}{ Mean } & \multicolumn{2}{|l|}{ Range } & \multirow[t]{2}{*}{$n$} & \multirow[t]{2}{*}{ Mean } & \multicolumn{2}{|l|}{ Range } \\
\hline & & & Maximum & Minimum & & & Maximum & Minimum \\
\hline Weight (g) & 42 & 262.06 & 426.00 & 75.00 & 9 & 119.55 & 155.9 & 94.8 \\
\hline Carapace length & 42 & 70.09 & 82.23 & 80.71 & 9 & 60.42 & 67.25 & 52.28 \\
\hline Carapace width & 42 & 67.77 & 80.71 & 47.87 & 9 & 59.45 & 64.97 & 50.09 \\
\hline \multicolumn{9}{|l|}{ Major chela ${ }^{\mathrm{a}}$} \\
\hline Height & 37 & 27.12 & 38.90 & 11.51 & 8 & 14.32 & 15.73 & 11.93 \\
\hline Width & & 19.15 & 25.74 & 8.71 & & 10.08 & 11.46 & 8.66 \\
\hline Length & & 57.64 & 79.65 & 30.05 & & 38.43 & 42.60 & 32.98 \\
\hline \multicolumn{9}{|l|}{ Minor chela ${ }^{\mathrm{a}}$} \\
\hline Height & 40 & 15.79 & 21.44 & 9.67 & 8 & 10.33 & 11.79 & 8.16 \\
\hline Width & & 11.64 & 42.71 & 6.00 & & 7.43 & 8.19 & 6.44 \\
\hline Length & & 48.89 & 65.44 & 28.85 & & 36.49 & 38.84 & 31.50 \\
\hline Ratio of major-to-minor chelae height & 37 & 1.70 & 2.00 & 1.19 & 8 & 1.39 & 1.48 & 1.24 \\
\hline \multicolumn{9}{|l|}{ Merus length of pereiopods ${ }^{\mathrm{a}, \mathrm{b}}$} \\
\hline Leg 2 & 37 & 62.73 & 78.63 & 36.43 & 8 & 39.56 & 44.62 & 32.20 \\
\hline Leg 3 & 39 & 65.70 & 80.81 & 38.60 & 7 & 42.09 & 47.73 & 34.39 \\
\hline Leg 4 & 36 & 61.95 & 77.36 & 22.51 & 9 & 41.07 & 47.34 & 34.87 \\
\hline Number of eggs ${ }^{\mathrm{c}, \mathrm{d}}$ & $\mathrm{n} / \mathrm{a}$ & $\mathrm{n} / \mathrm{a}$ & $\mathrm{n} / \mathrm{a}$ & $\mathrm{n} / \mathrm{a}$ & 4 & 2079 & 2308 & 1891 \\
\hline Egg diameter ${ }^{\mathrm{c}}$ & $\mathrm{n} / \mathrm{a}$ & $\mathrm{n} / \mathrm{a}$ & $\mathrm{n} / \mathrm{a}$ & $\mathrm{n} / \mathrm{a}$ & 4 & $\mathrm{n} / \mathrm{a}^{\mathrm{e}}$ & 2.25 & 2.00 \\
\hline
\end{tabular}

All measurements of length are in mm unless specified

a Damaged and regenerating limbs excluded

b Average of left and right measurements for each individual

c Counts from four ovigerous females

d 20 eggs measured per female

${ }^{\mathrm{e}}$ Egg size is stage-dependent

to be regenerating; therefore, the number of regenerating chelae reported is likely to be an underestimate.

The crabs were categorized by carapace age, based on Lovrich and Vinuesa (1993, see also Lovrich et al. 2002): (1) postmoult, in which the carapace was soft, bright red, lightly calcified, and lacking in epibionts; (2) early intermoult, in which the carapace was hard and brittle, bright red, and lacking in epibionts; (3) intermoult, in which the carapace was hard and brittle, red or dark pink, and bearing epibionts; or (4) premoult, in which the carapace was hard and brittle, pale pink, and bearing epibionts, and the new carapace was visible beneath the old. The 
reproductive state of females was evaluated as follows: (1) virginal: clean pleopods; (2) ovigerous: pleopods bearing a clutch of eggs; (3) postovigerous: pleopods and setae brown with no eggs; or (4) sterile: pleopods absent or female bearing a parasite under the abdominal flap. For each ovigerous female, the eggs were counted and the diameters and development of 20 haphazardly selected eggs were determined. Finally, we dissected a subset of the male and female crabs and examined them for internal signs of disease or parasites.

\section{Results}

Fifty-one $P$. birsteini-42 males and 9 females-were recovered in the crab traps. The mean wet-weight of the males was more than double that of the females. Neither parasites nor egg clutches were removed before wetweights were recorded. The average carapace length (CL) and carapace width $(\mathrm{CW})$ were greater in males than in females (two-tailed $t$-tests: $t=3.467, \mathrm{df}=49, P=0.001$ and $t=3.067, \mathrm{df}=49, P=0.003$, respectively). CL was slightly larger than $\mathrm{CW}$ in both sexes (one-tailed, paired $t$ tests: $t=5.626$, $\mathrm{df}=41, P<0.001$ for males and $t=2.028, \mathrm{df}=8, P=0.039$ for females). Chelipeds were dimorphic in both sexes, with the major chela on the right and the minor chela on the left. The dimorphism was stronger in males, in which the ratio of heights of the major-to-minor chelae was greater than those observed in females (one-tailed Welch's $t$-test: $t=6.956, \mathrm{df}=31.539$, $P<0.001)$. In one male, the asymmetry of the chelae was reversed, with the major chela appearing on the left.

Significant correlations were detected between $\ln (\mathrm{CL})$ and $\ln$ (wet-weight) [Spearman rank correlations: $\rho=0.900, \quad \mathrm{df}=40, \quad P<0.001$ for males; $\rho=1.00$, $\mathrm{df}=4, P=0.003$ for females], $\ln (\mathrm{CL})$ and $\ln$ (major chela height) $[\rho=0.726, \quad \mathrm{df}=36, \quad P<0.001$ for males; $\rho=0.952$, df $=6, P=0.001$ for females], and $\ln (\mathrm{CL})$ and $\ln (\mathrm{CW})[\rho=0.937$, df $=40, P<0.001$ for males; $\rho=0.983$, df $=7, P<0.001$ for females]. The scatterplots are shown for both males and females in Fig. 2 (see Table 2 for complete morphometric details). Visual examination of the data suggested no apparent changes in slope that would allow the size at morphometric maturity to be calculated (cf. Somerton 1980).

Fifteen males and three females were missing or regenerating limbs. Loss or regeneration of chelae was observed in five males and one female. The female was missing both chelae. Although no regrowth was evident in this female, blackened stumps indicated the formation of scar tissue. One male had lost both chelae, presumably during the same intermoult period, and both were in the early stages of regeneration. The major chela was absent
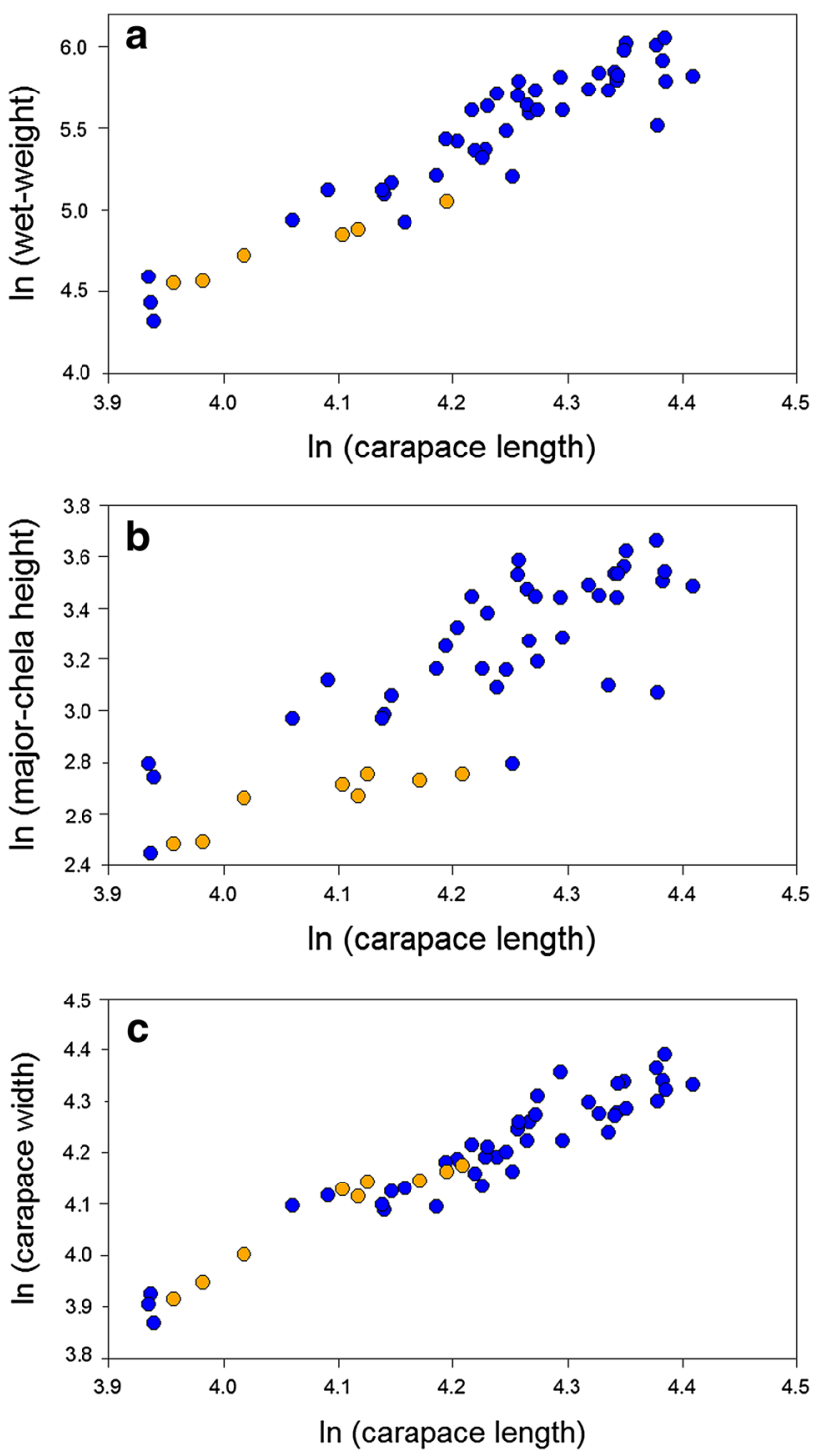

Fig. 2 Morphometric relationships in Paralomis birsteini. Parameters plotted against $\ln$ (carapace length) include a $\ln ($ weight); b $\ln$ (major-chela height); $\mathbf{c} \ln$ (carapace width). Blue circles represent males and orange circles represent females

from two males and the remaining two males each displayed a regenerating chela: one major and one minor. A sixth male had a significantly damaged major chela. Pereopod loss or regeneration was observed in 12 males and 3 females. Of the sample of 153 pairs of pereopods, 2 pairs included a missing pereopod and 16 pairs included a regenerating pereopod (Fig. 3). One male was completely missing a pereopod, and one female was missing the dactyl of one pereopod; the latter female was also the one that was missing both chelae. Eight males and two females each had one regenerating pereopod, and three males each had two regenerating pereopods. One female was also missing an antenna, the base of which was blackened with scar tissue. The percent regrowth was estimated for the 16 pairs of 


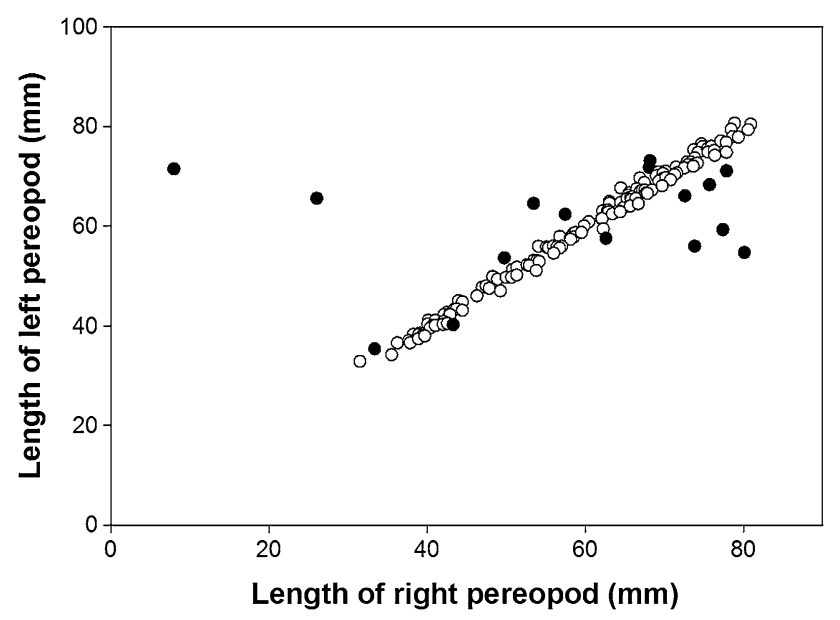

Fig. 3 Comparison of the lengths of pairs of pereopods of Paralomis birsteini. Filled circles represent regenerating pereopods, determined as outliers in the dataset

pereopods in which one was regenerating. The regenerating pereopods were $11-95 \%$ the size of the opposing, fully grown pereopods: one showed $11 \%$ regrowth, one showed $40 \%$ regrowth, four showed $\sim 76 \%$ regrowth, and 9 showed $92-95 \%$ regrowth.

The $P$. birsteini were typically red or dark pink and all appeared to be at the early-intermoult or intermoult stage. Each individual had a brittle carapace, although the carapaces appeared weak and lightly calcified, and they compressed under light pressure. In contrast, the exoskeletons of the chelae appeared much stronger. There was little fouling or damage to either carapaces or limbs, but small, stalked hydrozoans were commonly found growing as epibionts on the exoskeletons. Occasionally small, black marks, presumably the result of biofouling, were evident on the exoskeletons.

The largest four females were ovigerous, carrying full clutches with 1891, 2009, 2109, and 2308 eggs (CL 64.85, $61.88,67.25$, and $66.37 \mathrm{~mm}$, respectively; Fig. 4a). Three of these clutches contained eggs with a diameter of $\sim 2.0 \mathrm{~mm}$ that were in the early stages of development and without ocular development. The fourth clutch was at a later stage: the eggs were eyed, averaged $2.25 \mathrm{~mm}$ in diameter, and limb development and setation of the tail fan were evident (Fig. 4b, c). Of the five remaining females, the four smallest females (CL 52.28-60.59 mm) were carrying the parasitic rhizocephalan barnacle Briarosaccus callosus beneath the abdominal flap (Fig. 4d, e). One of these parasites was infested with hyperparasites (Fig. 4e), probably early subadults of the cryptoniscid isopod Liriopsis pygmaea (Lovrich et al. 2004; Peresan and Roccatagliata 2005). The final female showed signs of a past infection of $B$. callosus, as evidenced by scarring under the abdominal flap. Three of the parasitized females had visible pleopods under their abdominal flaps. The final parasitized female and the female showing signs of past infection had no visible pleopods (Fig. 4e), indicating that they were feminized males; feminization of males is a common side-effect of infection by B. callosus (Hoggarth 1990). B. callosus was also observed beneath the abdominal flap of two males (CL 69.88 and $70.27 \mathrm{~mm}$ ) and on the rudimentary fifth leg of a third male (CL $76.39 \mathrm{~mm}$ ). In total, $14 \%$ of the crabs showed signs of parasitism by $B$. callosus. One male and one female were each carrying two B. callosus under their abdominal flaps (Fig. 4d).

Twelve males and two females were dissected, and the rest were kept intact for later use. Varying degrees of gill necrosis were observed in 6 males (Fig. 4f). In some individuals, either small areas of necrosis were scattered throughout the gills or necrosis was evident across the tops of all of the gills but the bases of the gills appeared healthy. In other crabs, some sections of the gills were blackened throughout and reduced in size, whereas other sections appeared undamaged. The rest of the dissected individuals appeared healthy. A new carapace was growing beneath the current carapace in all individuals, and no parasites were observed beneath the carapaces of any of the crabs.

\section{Discussion}

Our data support previous observations that populations of lithodids are established on the continental slope off the WAP (Aronson et al. 2015). The presence of males and females, including ovigerous females with developing broods, indicates the population off Marguerite Bay is reproductively viable. Egg size appeared to increase with developmental stage, as has been observed in other lithodids (Long and Van Sant 2016, but see Stevens 2006). The larger number of males recovered in the traps-4.7 times the number of females-could be explained by reduced feeding of females, especially ovigerous females (Branford 1979; Miller 1990). Seasonal drops in female catch numbers have been observed in some crustaceans during egg development, reflecting their reduced food intake (e.g., Kennelly and Watkins 1994). Crab trapping is also often biased toward larger males, which enter the traps more readily (Miller 1990). Similarly disproportionate sex ratios have been reported for multiple species of lithodids collected using a comparable trapping technique in the deep sea off the South Orkney Islands and in the northern Scotia Sea (Anosov et al. 2014).

Females were typically smaller than males and weighed on average half as much. As is common in lithodids, the dimorphism of the chelae was stronger in males than in females. Interestingly, despite the Antarctic deep sea being undersaturated with regard to calcium carbonate (Lebrato 

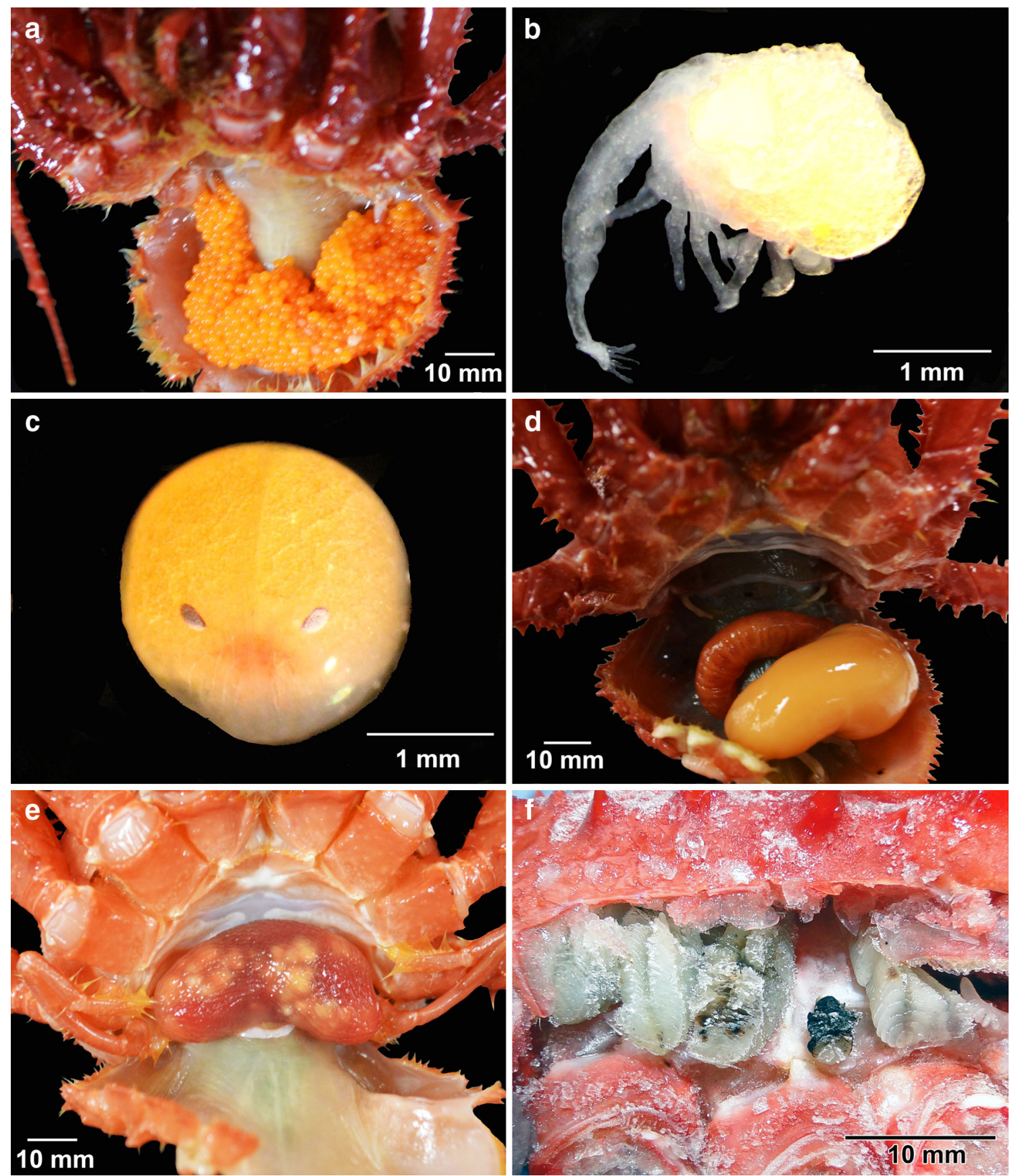

Fig. 4 a Ovigerous female Paralomis birsteini. b Lateral view of developing embryo with limbs and telson including terminal setae clearly visible. c Yolk-rich egg with eye placodes clearly visible. d Abdominal flap of female P. birsteini pulled back, showing two

et al. 2016), the chelae appeared sturdy with well-defined teeth. In contrast, the carapace and pereopods appeared weakly calcified. A heavily calcified carapace may not be necessary, because predation pressure on the lithodids is negligible (Aronson et al. 2015). P. birsteini collected off the WAP feed on a generalized diet of calcified invertebrates (unpublished data), requiring well-calcified chelae. parasitic rhizocephalan barnacles (Briarosaccus callosus). e Feminized male $P$. birsteini carrying $B$. callosus infested with hyperparasites and with no visible pleopods. f Gill necrosis in a male $P$. birsteini

The apparent difference in calcification suggests the crabs may minimize the energetic cost of calcification in the bathyal environment off Antarctica (see Watson et al. 2012).

All of the lithodids recovered in the traps had a CL $>50 \mathrm{~mm}$ and were most likely adults (Thatje et al. 2008; Hall and Thatje 2010). Based on the 25-mm mesh used to 
cover the crab pots, smaller individuals should have been able to escape. Juvenile P. birsteini as small as $11 \mathrm{~mm}$ were observed in images within our study area (Aronson et al. 2015), perched on rocks and on sea stars. This latter behaviour has also been described in the Arctic, where juvenile Paralithodes camtschaticus apparently 'hitchhike' sea stars for camouflage, shelter, and food (Powell and Nickerson 1965; Dew 1990; Barry et al. 2016).

Missing or regenerating limbs were evident in $35 \%$ of the crabs recovered. The incidence was higher than the 9\% reported from image analysis of the same site (Aronson et al. 2015). The imaging study probably underestimated the incidence of regenerating limbs because the later stages of regeneration would have been difficult to discern in the images. The relatively high occurrence of missing or regenerating limbs is surprising considering the lack of predators of lithodids. Such injuries in females are often incurred during precopulatory embrace (Dvoretsky and Dvoretsky 2009 and references therein): prior to mating, lithodids engage in an embrace, in which the male grasps the female by her chelae as she approaches a moult. The female that was missing both chelae and the dactyl of a pereopod was ovigerous, and the injuries were likely sustained during such an embrace. Injuries to males were most likely caused by agonistic encounters with conspecific males. In both sexes, the lightly calcified carapace that we observed would make $P$. birsteini more vulnerable to injury than other, more heavily calcified lithodids.

Lost limbs regenerate slowly in Crustacea, increasing incrementally over multiple moult cycles. In the present study, regenerating pereopods were seen at $\sim 11,40,76$, and $92-95 \%$ of the opposing full-sized pereopods, suggesting that we observed four stages of regrowth. Based on the four observed stages, we suggest that at least five moult cycles are required for $P$. birsteini to regenerate a complete limb. Comparable programs of limb-regeneration have been reported for the lithodids Paralithodes camtschaticus (five to seven moults; Edwards 1972) and Paralithodes platypus (five or more moults; Lysenko et al. 2000) from the Bering Sea, and for the brachyurans Chionoecetes bairdi and Chionoecetes opilio from the Sea of Okhotsk (four moults; Selin 2003).

Gill necrosis and parasitism were prevalent in the population of $P$. birsteini. In several crustaceans outside Antarctica, gill necrosis has been linked to accumulation of cadmium (Soegianto et al. 1999; Barbieri 2007). Cadmium is more concentrated in the seawater surrounding Antarctica than in other oceans (Sañudo-Wilhelmy et al. 2002) and has been reported in Antarctic benthic organisms (Bargagli et al. 1996; Lebrato et al. 2013). Elevated cadmium levels are, therefore, a possible explanation for the necrosis observed here.
Briarosaccus callosus can sterilize both male and female lithodids, raising the possibility that a significant proportion of the population of $P$. birsteini is infertile. The prevalence of $B$. callosus varies as a function of size in lithodids, with higher rates of infestation observed in smaller individuals (Lovrich et al. 2004). The parasite has also been shown to limit crustacean growth (Hawkes et al. 1987; Watters 1998) which enhances the bias in infestation toward smaller sizes of hosts. In the present study, a similar relationship was seen in females, with $B$. callosus found only in the smallest-four females (CL 52.3-60.6 mm). The trend was less prevalent in males, for which the parasite was observed only in three average-sized individuals (CL 64.2-69.4 mm). We found a higher prevalence of parasitism in females, but previous studies of lithodids have reported conflicting results on the subject of gender bias (Watters 1998; Poltev 2008). The prevalence of parasites may vary by location (Otto and MacIntosh 1996; Lovrich et al. 2004); compared with the $14 \%$ of $P$. birsteini infected by $B$. callosus in the present study, rates of parasitism ranging from $<1 \%$ to as high as $75 \%$ have been reported for lithodid populations globally (Hawkes et al. 1985; Hoggarth 1990; Watters 1998; Anosov et al. 2014). Consequently, the prevalence could be different in other $P$. birsteini populations.

Our data corroborate previous suggestions that viable populations of lithodids are living on the continental slope off the WAP. Adults are successfully reproducing and eggs are developing. The current status of the population, combined with the environmental conditions and the availability of food resources (Aronson et al. 2015), highlights the potential for an upward expansion of lithodids to the outer continental shelf off the western Antarctic Peninsula.

Acknowledgements We thank the captain and crew of the RV Laurence $M$. Gould, as well as J. W. Bailey, M. E. Deal, D. S. Ellis, W. R. James, K. McCaffrey, C. J. Randall, A. W. Randolph, D. Roccatagliata, T. Sayre-McCord, J. C. Schiferl, R. van Woesik, and K. Wicks, for assistance and logistical support. Our research was supported by the U.S. National Science Foundation under grants ANT1141877 to R.B.A. and ANT-1141896 to J.B.M. Additional support derived from an Endowed Professorship in Polar and Marine Biology from the University of Alabama at Birmingham, held by J.B.M. This is contribution no. 189 from the Institute for Research on Global Climate Change at the Florida Institute of Technology.

\section{Compliance with ethical standards}

Conflict of interest The authors declare that they have no conflict of interest.

Ethical approval All applicable international, national, and/or institutional guidelines for the care and use of animals were followed.

Open Access This article is distributed under the terms of the Creative Commons Attribution 4.0 International License 
(http://creativecommons.org/licenses/by/4.0/), which permits unrestricted use, distribution, and reproduction in any medium, provided you give appropriate credit to the original author(s) and the source, provide a link to the Creative Commons license, and indicate if changes were made.

\section{References}

Ahyong ST, Dawson EW (2006) Lithodidae from the Ross Sea, Antarctica, with descriptions of two new species (Crustacea: Decapoda: Anomura). Zootaxa 1303:45-68

Anosov SE, Spiridonov VA, Neretina TV, Uryupova EF, Schepetov D (2014) King crabs of the western Atlantic sector of Antarctic and adjacent areas: new records, molecular barcode data and distribution (Crustacea: Decapoda: Lithodidae). Polar Biol 38:231-249

Arana EP, Retamal MA (1999) New distribution of Paralomis birsteini Macpherson, 1988 in Antarctic waters (Anomura, Lithodidae, Lithodinae). Invest Mar Valparaíso 27:101-110

Aronson RB, Thatje S, Clarke A, Peck LS, Blake DB, Wilga CD, Seibel BA (2007) Climate change and invasibility of the Antarctic benthos. Annu Rev Ecol Evol Syst 38:129-154

Aronson RB, Smith KE, Vos SC, McClintock JB, Amsler MO, Moksnes P-O, Ellis DS, Kaeli J, Singh H, Bailey JW, Schiferl JC, van Woesik R, Martin MA, Steffel BV, Deal ME, Lazarus SM, Havenhand JN, Swalethorp Kjellerup S, Thatje S (2015) No barrier to emergence of bathyal king crabs on the Antarctic shelf. Proc Natl Acad Sci USA 122:12997-13002

Barbieri E (2007) Use of oxygen consumption and ammonium excretion to evaluate the sublethal toxicity of cadmium and zinc on Litopenaeus schmitti (Burkenroad, 1936, Crustacea). Water Environ Res 79:641-646

Bargagli R, Nelli L, Ancora S, Focardi S (1996) Elevated cadmium accumulation in marine organisms from Terra Nova Bay (Antarctica). Polar Biol 16:513-520

Barry JP, Taylor JR, Kuhnz LA, De Vogelaere AP (2016) Symbiosis between the holothurian Scotoplanes sp. A and the lithodid crab Neolithodes diomedeae on a featureless bathyal sediment plain. Mar Ecol. doi:10.1111/maec.12396

Branford JR (1979) Locomotor activity and food consumption by the lobster Homarus gammarus. Mar Behav Physiol 6:13-24

Britayev TA, Rzhavsky AV, Pavlova LV, Dvoretskij AV (2010) Studies on impact of the alien red king crab (Paralithodes camtschaticus) on the shallow water benthic communities of the Barents Sea. J Appl Ichthyol 26(Suppl 2):66-73

Dew CB (1990) Behavioral ecology of podding red king crab, Paralithodes camtschatica. Can J Fish Aquatic Sci 47:1944-1958

Dvoretsky AG, Dvoretsky VG (2009) Limb autotomy patterns in Paralithodes camtschaticus (Tilesius, 1815), an invasive crab, in the coastal Barents Sea. J Exp Mar Biol Ecol 337:20-27

Edwards JS (1972) Limb loss and regeneration in two crabs: the king crab Paralithodes camtschatica and the tanner crab Chionoecetes bairdi. Acta Zool 53:105-112

Falk-Petersen F, Renaud P, Anisimova N (2011) Establishment and ecosystem effects of the alien invasive red king crab (Paralithodes camtschaticus) in the Barents Sea-a review. ICES J Mar Sci 68:479-488

Grosholz ED, Ruiz GM, Dean CA, Shirley KA, Maron JL, Connors PG (2000) The impacts of a nonindigenous marine predator in a California bay. Ecology 81:1206-1224

Hall S, Thatje S (2009) Global bottlenecks in the distribution of marine Crustacea: temperature constraints in the family Lithodidae. J Biogeogr 36:2125-2135
Hall S, Thatje S (2010) King crabs up-close: ontogenetic changes in ornamentation in the family Lithodidae (Crustacea, Decapoda, Anomura), with a focus on the genus Paralomis. Zoosystema 32:495-524

Hall S, Thatje S (2011) Temperature-driven biogeography of the deep-sea family Lithodidae (Crustacea: Decapoda: Anomura) in the Southern Ocean. Polar Biol 34:363-370

Hawkes CR, Meyers TR, Shirley TC (1985) Parasitism of the blue king crab, Paralithodes platypus, by the rhizocephalan, Briarosaccus callosus. J Invertebr Pathol 45:252-253

Hawkes CR, Meyers TR, Shirley TC (1987) Growth of Alaskan blue king crabs, Paralithodes platypus (Brandt), parasitized by the rhizocephalan Briarosaccus callosus Boschma. Crustaceana 52:78-84

Hoggarth DD (1990) The effects of parasitism by the rhizocephalan, Briarosaccus callosus Boschma on the lithodid crab, Paralomis granulosa (Jacquinot) in the Falkland Islands. Crustaceana 59:156-170

Kennelly SJ, Watkins D (1994) Fecundity and reproductive period, and their relationship to catch rates of spanner crabs, Ranina ranina, off the east coast of Australia. J Crust Biol 1:146-150

Lebrato M, McClintock JB, Amsler MO, Ries JB, Egilsdottir H, Amsler CD, Challener RC, Schram JB, Mah CL, Cuce J, Baker BJ (2013) From the Arctic to the Antarctic: trace and rare elemental geochemistry of echinoderm skeletons. Ecology 94:1434

Lebrato M, Andersson AJ, Ries JB, Aronson RB, Lamare MD, Koeve $\mathrm{W}$, Oschlies A, Iglesias-Rodriguez MD, Thatje S, Amsler M, Vos SC, Jones DOB, Ruhl HA, Gates AR, McClintock JB (2016) Benthic marine calcifiers coexist with $\mathrm{CaCO} 3$-undersaturated seawater worldwide. Global Biogeochem Cycles 30:1038-1053

Long WC, Van Sant SB (2016) Embryo development in golden king crab (Lithodes aequispinus). Fish Bull 114:67-77

Lovrich GA, Vinuesa JH (1993) Reproductive biology of the false southern king crab (Paralomis granulosa, Lithodidae) in the Beagle Channel, Argentina. Fish Bull 91:664-675

Lovrich GA, Vinuesa JH, Smith BD (2002) Growth, maturity, and mating of male southern king crab (Lithodes santolla) in the Beagle Channel, Argentina. Crabs in cold water regions: biology, management, and economics. Alaska Sea Grant College Progr Rep 2:147-168

Lovrich GA, Roccatagliata D, Peresan L (2004) Hyperparasitism of the cryptoniscid isopod Liriopsis pygmaea on the lithodid Paralomis granulosa from the Beagle Channel, Argentina. Dis Aquat Organ 58:71-77

Lysenko VN, Selin NI, Fedotov PA (2000) Autotomy and regeneration of limbs in the male blue king crab Paralithodes platypus from the Bering Sea and the Sea of Okhotsk. Russ J Mar Biol 26:364-366

Miller RJ (1990) Effectiveness of crab and lobster traps. Can J Fish Aquat Sci 47:1228-1251

Molinos JG, Halpern BS, Schoeman DS, Brown CJ, Kiessling W, Moore PJ, Pandolfi JM, Poloczanska ES, Richardson AJ, Burrows MT (2015) Climate velocity and the future global redistribution of marine biodiversity. Nat Clim Change 6:83-88

Otto RS, MacIntosh RA (1996) Observations on the biology of the lithodid crab Paralomis spinosissima from the Southern Ocean near South Georgia. High latitude crabs: biology, management and economics. Alaska Sea Grant College Progr Rep 96-02:627-647

Oug E, Cochrane SK, Sundet JH, Norling K, Nilsson HC (2011) Effects of the invasive red king crab (Paralithodes camtschaticus) on soft-bottom fauna in Varangerfjorden, northern Norway. Mar Biodivers 41:467-479

Peresan L, Roccatagliata D (2005) First record of the hyperparasite Liriopsis pygmaea (Cryptoniscidae, Isopoda) from a 
shizocephalan parasite of the false king crab Paralomis granulosa from the Beagle Channel (Argentina), with a redescription. J Nat Hist 39:311-324

Poltev YN (2008) Parasitism of the rhizocephalan Briarosaccus callosus on the crab Paralomis verrilli (Crustacea: Lithodidae) in the waters of southeast Sakhalin. Russ J Mar Biol 34:159-165

Powell GC, Nickerson RB (1965) Aggregations among juvenile king crabs (Paralithodes camtschatica, Tilesius) Kodiak, Alaska. Anim Behav 13:374-380

Sañudo-Wilhelmy SA, Olsen KA, Scelfo JM, Foster TD, Flegal AR (2002) Trace metal distributions off the Antarctic Peninsula in the Weddell Sea. Mar Chem 77:157-170

Schmidtko S, Heywood KJ, Thompson AF, Aoki S (2014) Multidecadal warming of Antarctic waters. Science 346:1227-1230

Selin NI (2003) Regeneration of limbs in males of the tanner crabs Chionoecetes bairdi and Ch. opilio. Russ J Mar Biol 29:171-174

Soegianto A, Charmantier-Daures M, Trilles J-P, Charmantier G (1999) Impact of cadmium on the structure of gills and epipodites of the shrimp Penaeus japonicas (Crustacea: Decapoda). Aquat Living Resour 12:57-70
Somerton DA (1980) A computer technique for estimating the size of sexual maturity in crabs. Can J Fish Aquat Sci 37:1488-1494

Stevens BG (2006) Embryonic development and morphometry in the blue king crab, Paralithodes platypus, studied by image and cluster analysis. J Shellfish Res 25:569-576

Thatje S, Anger K, Calcagno JA, Lovrich GA, Pörtner HO, Arntz WE (2005) Challenging the cold: crabs reconquer the Antarctic. Ecology 86:619-625

Thatje S, Hall S, Hauton C, Held C, Tyler P (2008) Encounter of lithodid crab Paralomis birsteini on the continental slope of Antarctica, sampled by ROV. Polar Biol 31:1143-1148

Watson S-A, Peck LS, Tyler PA, Southgate PC, Tan KS, Day RW, Morley SA (2012) Marine invertebrate skeleton size varies with latitude, temperature and carbonate saturation. Global Change Biol 18:3026-3038

Watters G (1998) Prevalences of parasitized and hyperparasitized crabs near South Georgia. Mar Ecol Prog Ser 170:215-229 